\title{
Pengaruh Literasi terhadap Keterampilan Membaca pada Siswa Kelas IV SD Inpres 12 Kabupaten Sorong
}

\author{
Rizal Hermawan ${ }^{1}$, Nouval Rumaf ${ }^{2}$ \& Solehun $^{3}$
}

Program Studi PGSD, Universitas Pendidikan Muhammadiyah Sorong, Indonesia

$\bowtie$ E-mail: hermawanrizal124@gmail.com

\begin{abstract}
Abstrak
Membaca merupakan kemampuan yang paling mendasar sebagai bekal untuk mempelajari segala sesuatu, dalam literasi membaca merupakan bentuk pembelajaran yang sangat menarik dan penting bagi guru dan peserta didik agar suatu pembelajaran mudah dipahami atau dimengerti saat melakukan kegiatan membaca, menulis maupun berkomunikasi. Penelitian ini bertujuan untuk mengetahui apakah pendekatan literasi dapat berpengaruh terhadap keterampilan membaca pada siswa kelas IV SD Inpres 12 Kabupaten Sorong. Pendekatan penelitian ini adalah kuantitatif dengan desain quasi experimental design. Populasi penelitian ini yaitu seluruh siswa kelas IV SD Inpres Kabupaten Sorong yang berjumlah 67 siswa, dimana kelas IV A sebanyak 20 siswa, kelas IV B sebanyak 27 siswa dan kelas IV C sebanyak 20 siswa. Pengambilan sampel dilakukan dengan teknik sampling yaitu random sampling. Teknik pengumpulan data yang digunakan adalah pre test dan post test. Teknik analisis data yang digunakan adalah uji normalitas, uji homogenitas dan uji t. Hasil penelitian ini menunjukan bahwa terdapat pengaruh literasi terhadap keterampilan membaca pada siswa kelas IV SD Inpres 12 Kabupaten Sorong. Hal ini ditunjukan oleh nilai $t_{\text {hitung }}$ sebesar 13.220 dengan $\mathrm{dk}=\mathrm{n}$ $2(40-2=38)$ diperoleh $t_{\text {tabel }} 2.024$. Berdasarkan hasil analisis data nilai yaitu $t_{\text {hitung }}>t_{\text {tabel }}(13.220>$ 2.024) maka hipotesis diterima.
\end{abstract}

Kata Kunci: Literasi; Keterampilan Membaca; Pembelajaran Bahasa Indonesia.

\begin{abstract}
Reading is the most basic ability as a provision to learn everything, in literacy reading is a form of learning that is very interesting and important for teachers and students so that a learning is easily understood or understood when reading, writing or communicating. This study aims to determine whether the literacy approach can affect reading skills in fourth grade students of SD Inpres 12, Sorong Regency. This research approach is quantitative with a quasi experimental design. The population of this research is all students of class IV SD Inpres Sorong Regency, amounting to 67 students, where class IV A is 20 students, class IV B is 27 students and class IV C is 20 students. Sampling is done by sampling technique that is nonprobability sampling. Data collection techniques used were pre test and post test. Data analysis techniques used were normality test, homogeneity test and t test. The results of this study indicate that there is an influence of literacy on reading skills in fourth grade students of SD Inpres 12, Sorong Regency. This is indicated by the value of $t_{\text {arithmetic }}$ amounted to 13,220 with $d k=n-2(40-2=38)$ obtained table 2,024. Based on the results of data analysis values, namely $t_{\text {arithmetic }}>t_{\text {table }}(13,220>2,024)$, the hypothesis is accepted.
\end{abstract}

Keywords: Literacy; Reading Skills; Indonesian Language Learning. 


\section{PENDAHULUAN}

Membaca merupakan mengungkapkan suatu imajinasi terhadap suatu pembaca yang disukai khalayak ramai dan juga dimengerti oleh seseorang. Membaca dapat juga diartikan sebagai proses menerima informasi melalui sebuah tulisan yang umum. Berkaitan dengan membaca sangat erat kaitannya dengan Literasi.

Literasi menjadi sangat penting hal ini sesuai dengan amanat pendidikan di indonesia bahwa pendidikan saat ini terutama di tingkat SD dalam pembelajaran diarahkan pada penguatan literasi. Literasi merupakan sebuah konsep yang memiliki makna kompleks, dinamis, yang terus ditafsirkan dan didefinisikan dengan beragam cara dan sudut pandang (Rumaf, 2019). Konsep tersebut perlu dimaknai maksud dari literasi yang di harapkan. Selnjutnya menurut (Santoso, 2016) Literasi dapat diartikan sebagai kemampuan membaca dan kemampuan menulis atau dapat disebut dengan melek aksara atau keberaksaraan.

Seseorang dapat dibilang literat jika mereka sudah dapat memahami suatu hal karena telah memahami informasi sebagai hasil dari membaca yang tepat dan melaksanakan pemahamannya sesuai dengan apa yang dia serap. Penguasaan literasi dalam segala bentuk ilmu pengetahuan sangat diperlukan karena dengan begitu akan ikut serta mendorong kemajuan suatu bangsa. Literasi sebagai sebuah kegiatan dalam menafsirkan atau menginterpretasikan segala bentuk ilmu pengetahuan akan membangun manusia yang memiliki pengetahuan yang luas.

Membaca merupakan kemampuan yang paling mendasar sebagai bekal untuk mempelajari segala sesuatu, dalam literasi merupakan bentuk pembelajaranan yang sangat menarik dan penting bagi guru dan peserta didik agar suatu pembelajaran mudah dipahami atau dimengerti saat melakukan kegiatan membaca, menulis maupun berkomunikasi. Tetapi dalam pembelajaran di Sekolah Dasar Inpres 12 Kabupaten Sorong dari banyaknya peserta didik beberapa masih kurang memahami pentingnya membaca dan menulis karena hal tersebut merupakan awal dari kegiatan pembelajaran maupun komunikasi harus memahami apa yang dibahas maupun ucapan.

Keterampilan dalam menggunakan bahasa biasanya mencantumkan empat keterampilan yang harus dikuasai oleh peserta didik, yakni keterampilan menyimak, keterampilan membaca, keterampilan berbicara dan keterampilan menulis. Keempat keterampilan tersebut saling berhubungan satu sama lain dan memiliki perannya masing-masing.

Gerakan literasi di sekolah adalah upaya dalam melakukan perubahan secara menyeluruh untuk kegiatan sekolah sebagai organisasi pembelajaran literasi sepanjang hayat. Upaya yang harus ditempuh dalam mewujud literasi berupa pembiasan membaca oleh peserta didik. Pembiasaan ini harus dilakukan dengan kegiatan membaca selama 15 menit dengan membaca buku non pembelajaran sebelum waktu pembelajaran dimulai. Materi baca berisi nilai-nilai budi pekerti berupa kearifan lokal, nasional dan global yang disampaikan sesuai tahap perkembangan peserta didik.

Dalam kemampuan membaca peserta didik dapat memiliki peran dan menjadi salah satu kunci kesuksesan dikehidupan seseorang, karena setiap informasi dan pengetahuan dapat diperoleh tidak terlepas dari kegiatan membaca. Bahwa semakin sering seseorang membaca buku maka semakin luas pengetahuan yang dimiliki, dan sebaliknya semakin jarang membaca buku maka pengetahuan yang dimiliki seseorang semakin terbatas. Tidak terkecuali bagi sebuah bangsa. Kemajuan peradaban sebuah bangsa juga ditentukan dari seberapa banyak masyarakatnya membaca (Ahmadi 2010).

Tidak berbeda dengan membaca pun memiliki peran tersendiri bagi kehidupan seseorang. Menurut Cakiroglu (2012) writing skill is more than a kinesthetic activity which is a more complex and higher level of cognitive activity that should be considered together with the reading skill. 
Dari pendapat yang diatas menyebutkan diketahui bahwa kegiatan menulis memiliki tingkatan yang sama dengan kegiatan membaca, dikarenakan ketika seseorang mampu untuk menulis maka secara tidak langsung seseorang tersebut juga mampu untuk membaca. Kegiatan menulis bukanlah kemampuan yang dapat dikuasai dengan sendirinya, melainkan proses pembelajaran panjang untuk menumbuh kembangkan tradisi menulis. Hal ini dapat mendorong seseorang sejak lahir didunia dapat belajar membaca maupun menulis dari orang tua atau lingkungan disekitarnya.

Selain itu proses pembelajaran dan hasil pembelajaran tidak dapat terlepas dari faktor guru. Guru memiliki peran penting dalam menciptakan proses pembelajaran yang efektif guna mencapai tujuan pembelajaran yang telah ditetapkan. Peran penting guru diharapkan mampu menerapkan strategi yang baik dalam rangka menciptkan sumber daya manusia yang berkualitas melalui pemahaman ketika membaca.

Upaya yang dilakukan guru di SD Inpres 12 Kabupaten Sorong dalam proses belajar mengajar telah maksimal tetapi dalam pendidikan literasi sudah tidak pernah melaksankan kegiatan literasi di sekolah dan juga daya serap pemahaman peserta didik berbeda-beda. Saat guru menjelaskan tidak sedikit peserta didik yang tidak memperhatikan dengan baik, ada yang cerita dengan teman, ada yang sibuk meruncing pensilnya, dan sebagainya. Hal inilah yang membuat pemahaman siswa tidak terfokus dengan pelajaran.

Oleh karena itu sebisa mungkin kita tanamkan kebiasaan membaca kepada siswa yang sebelumnya tidak mengetahui pentingnya membaca mulai paham dan sadar akan pentingnya membaca dan jangan terusmenerus bergantung kepada seorang guru disekolah saja namun juga bisa belajar dimana saja. Agar peserta didik tertarik untuk membaca dan kenalkanlah pada peserta didik buku yang memiliki banyak warna, dan juga gambar- gambar yang menarik dan imajinatif untuk menarik minat peserta didik dalam membaca, selain memiliki dampak yang besar dalam perkembangan minat peserta didik dalam membaca, dan agar peserta didik paham dengan apa yang dia baca buku bergambar merupakan alternatif dan efektif.

Pada perkembangan zaman yang begitu pesat setiap orang dituntut harus memiliki kegemaran dalam membaca maupun menulis guna memperoleh pengetahuan dalam wawasan yang sangat luas untuk meningkatkan kecerdasannya. Kemampuan membaca seseorang juga digunakan sebagai tolak ukur dalam tingkat keberhasilan dikehidupan bermasyarakat mereka. Di sekolah dasar kemampuan membaca menjadi hal yang memegang peranan penting, karena tanpa hal tersebut peserta didik akan mengalami sebuah kesulitan belajar pada saat itu dan pada masa yang akan datang.

Di Era sekarang ini tidak sedikit orang yang malas untuk membaca terlebih minimnya budaya membaca di lingkungan sekitar tempat kita tinggal, penyebab seseorang malas membaca sebenarnya tidak hanya datang dari faktor diri sendiri, melainkan ada faktor pendukung yaitu faktor pertama yang membuat rakyat indonesia malas membaca harga buku bacaan yang tergolong mahal akibatnya hanya sebagian kecil dari rakyat indonesia yang menyisihkan sebagian uangnya untuk membeli buku. Faktor kedua minat baca orang tua dan guru yang tergolong rendah banyak orang tua yang menyerahkan sepenuhnya pendidikan literasi baca kepihak sekolah namun sebenarnya anak lebih lama berada dirumah. Begitu juga di sekolah seorang guru dituntut menyelesaikan materi pembelajaran sesuai kurikulum akibatnya banyak guru yang lupa untuk memperkenalkan buku dan membaca kepada muridnya. Faktor ketiga yaitu kita masyarakat indonesia terbiasa membaca artikel yang instan di internet mungkin ini sudah menjadi hukum alam dengan kemajuan teknologi.

Berdasarkan wawancara dengan guru pada tanggal 20 Maret 2019, guru menjelaskan bahwa kegiatan literasi ini belum maksimal dalam pembelajaran literasi 
di setiap kelasnya. Karena gerakan literasi ini telah berjalan sekitar 2 tahun yang dilaksanakan di SD Inpres 12 Kabupaten sorong tetapi telah hilang atau tidak pernah dilaksanakan kembali pembelajaran dengan literasi. Pembiasaan membaca dilaksanakan pada pagi hari sebelum melaksanakan kegiatan pembelajaran ketika siang waktu istirahat dengan menjadwal setiap kelas secara bergantian setiap harinya. Pihak perpustakaan telah menyiapkan buku bacaan sesuai jadwal kelas yang akan melakukan sebuah kegiatan membaca di perpustakaan dengan memperhatikan kesesuaian atau tingkatan bacaan dan isi bacaannya.

Dengan adanya gerakan literasi sekolah yang berfokus pada pembiasaan membaca ini diharapkan dapat berperan dalam meningkatkan minat membaca siswa seiring keterlibatan guru yang sangat penting dalam upaya keberhasilan kegiatan tersebut.

Oleh karena itu sebisa mungkin kita tanamkan kebiasaan membaca kepada peserta didik yang sebelumnya tidak mengetahui pentingnya membaca melalui kegiatan pengaruh literasi dalam pembelajaran bahasa Indonesia. Agar peserta didik tertarik dalam membaca maka kita kenalkan pada buku yang menarik, penuh warna dan juga gambar- gambar yang menarik, imajinatif dan memiliki kearifan lokal dalam buku bacaan.

Jadi "Pengaruh Literasi Terhadap Keterampilan Membaca Dalam Pembelajaran Bahasa Indonesia Pada Siswa Kelas IV SD Inpres 12 Kabupaten Sorong" maka peneliti mengambil penelitian di sekolah tersebut karena permasalahan yang ditemukan dalam pembelajaran selama ini adalah lemahnya guru pada proses kegiatan pembelajaran literasi pada mata pelajaran bahasa Indonesia di sekolah tersebut, dan masih kurang maksimal menggunakan literasi sebelum pembelajaran dimulai, oleh karena ini peserta didik masih belum mampu membaca maupun menulis dengan lancar atau berkomunikasi.

\section{METODE PENELITIAN}

Jenis penelitian ini yaitu jenis penelitian eksperimen dengan menggunakan pendekatan kuantitatif sedangkan desain penelitian yang digunakan adalah kuasi eksperimen (Quasi Experimental Design) desain eksperimen mempunyai kelompok kontrol, tetapi tidak sepenuhnya dapat mengkontrol variabelvariabel luar yang mempengaruhi pelaksanaan eksperimen (Sugiyono, 2017).

Populasi dalam penelitian ini berjumlah 67 siswa yang tersebar ke dalam tiga kelas. Sampel yang digunakan adalah berjumlah 20 siswa dari teknik pengambilan sampel yang digunakan yakni teknik random sampling. Selanjutnya Teknik pengumpulan data yang digunakan peneliti dalam pengumpulan data yaitu Observasi, Tes, dan Dokumentasi. Dalam hal ini tes yang dimaksud adalah menggunakan pre test dan post test.

Teknik analisis data yang digunakan pada penelitian ini menggunakan teknik analisis inferensial. Namun sebelum dilakukan pengujian hipotesis perlu dilakukan uji awal atau biasa disebut dengan uji klasik yang terdiri atas berikut Uji Normalitas Data, Uji Homogenitas dan berakhir pada Uji Hipotesis.

\section{HASIL DAN PEMBAHASAN}

Uji normalitas dalam penelitian ini digunakan sebagai prasyarat untuk uji $\mathrm{T}$ dalam penelitian ini, data harus berdistribusi normal. Jika data tidak berdistribusi normal maka uji T tidak dapat dilanjutkan. Suatu distribusi dikatakan normal jika taraf signifikannya $>0,05$, sedangkan jika signifikannya $<0,05$ maka distribusinya dikatakan tidak normal. Untuk menguji normalitas data digunakan uji Tests of Normality. Dalam penelitian ini data yang terkumpul berupa data post test peserta didik yang kemudian di analisis oleh peneliti. Adapun data yang akan digunakan dalam menghitung uji normalitas, sebagai terlampir.

Hasil perhitungan uji normalitas data post test diperoleh jumlah $(\mathrm{N})$ pada kelas eksperimen dan kelas kontrol adalah 20 peserta didik. Rata-rata (Mean) dari kelas eksperimen adalah 68.15 dan kelas kontrol 
adalah 47.00. Standar deviasi dari kelas ekasperimen adalah 6.09 dan kelas kontrol 3.74. Difference positive dari kelas eksperimen 0.131 dan kelas kontrol 0.105. Difference negative untuk kelas eksperimen -0.155 dan kelas kontrol - 0.111. Kolmogorof-smirnov kelas eksperimen 0.695 dan kelas kontrol 0.498. kemudian berdasarkan perhitungan di atas dengan menggunakan kolmogorof-smirnov dapat disimpulkan bahwa rata-rata berdistribusi normal karena memiliki Asymp,Sig > 0.05 hasil belajar kelas eksperimen memiliki sig sebesar 0.719 dan kelas kontrol sebesar 0.965 sehingga dapat disimpulkan bahwa data tersebut berdistribusi normal. lebih jelas dapat dilihat pada tabel 1 .

Tabel 1. Uji normalitas

\begin{tabular}{|c|c|c|c|}
\hline \multicolumn{4}{|c|}{ One-Sample Kolmogorov-Smirnov Test } \\
\hline & & $\begin{array}{c}\text { Kelas } \\
\text { Eksperimen }\end{array}$ & $\begin{array}{c}\text { Kelas } \\
\text { Kontrol }\end{array}$ \\
\hline \multicolumn{2}{|l|}{ N } & 20 & 20 \\
\hline \multirow[t]{2}{*}{ Normal Parameters ${ }^{\mathrm{a}}$} & Mean & 68.1500 & 47.0000 \\
\hline & Std. Deviation & 6.09810 & 3.74166 \\
\hline \multirow{3}{*}{$\begin{array}{l}\text { Most Extreme } \\
\text { Differences }\end{array}$} & Absolute & .155 & .111 \\
\hline & Positive & .131 & .105 \\
\hline & Negative & -.155 & -.111 \\
\hline \multicolumn{2}{|c|}{ Kolmogorov-Smimov Z } & .695 & .498 \\
\hline \multicolumn{2}{|l|}{ Asymp. Sig. (2-tailed) } & .719 & .965 \\
\hline \multicolumn{2}{|c|}{ a. Test distribution is Normal. } & & \\
\hline
\end{tabular}

Hasil uji test of homogeneity of variances dilakukan sebagai prasyarat dalam analisis independent sampel $t$ test. Suatu data dikatakan homogeny jika taraf signifikansinya $>0.05$, sedangakan jika taraf sigifikansinya $<0.05$ maka distribusinya dikatakan tidak homogen. Dalam penelitian ini data yang terkumpul berupa post test yang kemudian akan dianalisis oleh peneliti, adapun dari hasil analisis homogenitas data post test diketahui bahwa nilai signifikansinya adalah 0.080 . Karena nilai signifikansinya lebih besar dari 0.05 yakni $0.080>0.05$ sehingga data hasil post test tersebut dapat dikatakan homogen.

Lebih rinci dapat dilihat pada tabel 2.
Tabel 2. Uji homogenitas

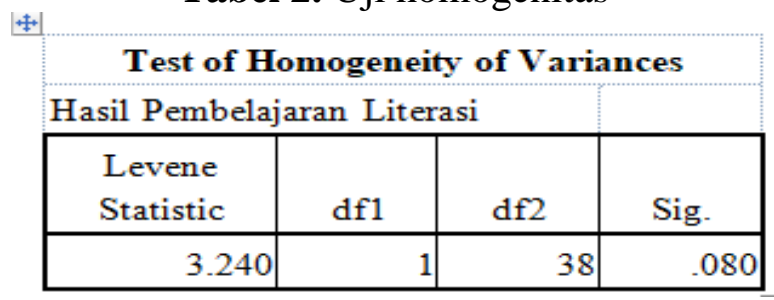

Uji t yang digunakan untuk mengetahui pengaruh literasi dalam pembelajaran bahasa Indonesia diketahui nilai $\mathrm{t}$ hitung sebesar 13.220 dengan $\mathrm{dk}=\mathrm{n}-2 \quad(40-2=38)$ diperoleh $t_{\text {tabel }}$ 2.024. Berdasarkan hasil analisis data nilai yaitu $t_{\text {hitung }}>t_{\text {tabel }}$ $(13.220>2.024)$, ini berarti bahwa $t_{\text {hitung }}$ lebih besar dari pada $t_{\text {tabel }}$ pada taraf $5 \%$ sehingga hipotesis dalam penelitian ini diterima dan dapat disimpulkan bahwa terdapat pengaruh literasi dalam pembelajaran bahasa Indonesia pada siswa kelas IV SD Inpres 12 Kabupaten Sorong.

Tabel 3. Independent sample $t$ test

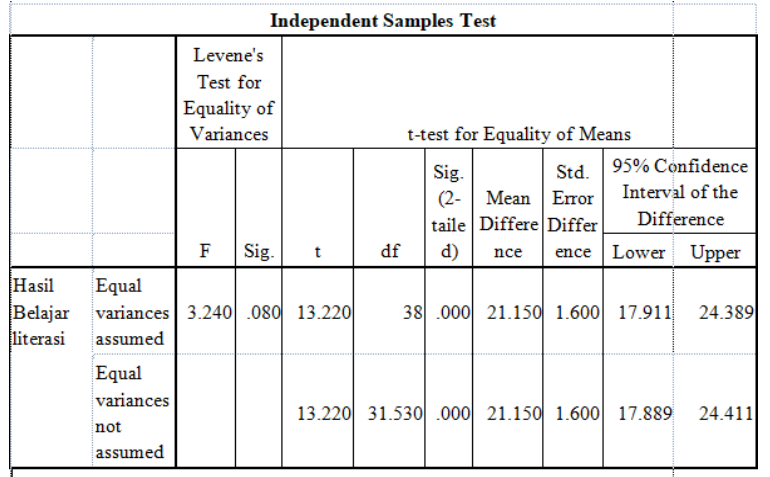

Paered samples test digunakan untuk mengetahui apakah terdapat perbedaan ratarata dua sampel yang berpasangan. Dua sempel yang dimaksud adalah sampel yang yang sama namun mempunyai dua data. Uji paired semples $t$ test merupakan bagian dari statistic parametric oleh karena itu, sebagian aturan dalam statistic parametrik data penelitian harus normal.

Hasil uji paired menunjukkan bahwa niali sig (2-tailed) sebesar $0.000<0.05$, maka dapat disimpulkan bahwa terdapat perbedaan yang nyata antara hasil pengaruh literasi dalam pembelajaran bahasa Indonesia. Lebih jelas dapat dilihat pada tabel 4. 
Tabel 4. Hasil uji paired

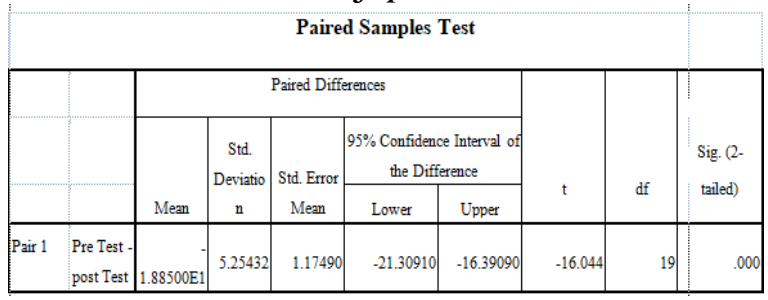

Dari hasil analisis dan diperoleh kesimpulan bahwa terdapat pengaruh literasi dalam pembelajaran bahasa Indonesia pada siswa kelas IV SD Inpres12 Kabupaten Sorong. Hal ini dapat dilihat dalam hasil analisis data yang diawali dengan pengolahan data dengan melakukan uji prasyarat, yaitu uji normalitas dan uji homogenitas data.

Berdasarkan pengolahan data uji normalitas diperoleh dari perhitungan menggunakan SPSS V16.0 Statistic For Windows, eksperimen dan kelas kontrol adalah 40 peserta didik. Rata-rata (Mean) dari kelas eksperimen adalah 68.15 dan kelas kontrol adalah 47.00. Standar deviasi dari kelas ekasperimen adalah 6.09 dan kelas kontrol 3.74. Difference positive dari kelas eksperimen 0.131 dan kelas kontrol 0.105. Difference negative untuk kelas eksperimen -0.155 dan kelas kontrol - 0.111. diketahui hasil belajar post test yaitu data post test kelas eksperimen memiliki sig sebesar 0.719 kelas kontrol 0.965 dimana Asymp, sig >0.05 sehingga dapat disimpulkan bahwa kelas IV berdistribusi normal dan layak digunakan untuk uji selanjutnya, yaitu uji homogenitas.

Pada uji homogenitas diketahui data post test kelas eksperimen dan kelas kontrol nilai signifikansinya adalah 0.080. Karena nilai signifikansinya lebih besar dari 0.05 yaitu $0.080>0.05$ maka data tersebut dapat dikatakan homogen dan dapat digunakan untuk uji selanjutnya, yaitu uji hipotesis menggunakan uji independent semples test dan uji paired semples tes.

Uji independent semples test dimana data yang diuji yaitu hasil data hubungan literasi dalam pembelajaran bahasa Indonesia dari kelas eksperimen dan kelas kontrol di peroleh $t_{\text {hitung }}$ sebesar 13.220 dengan $\mathrm{dk}=\mathrm{n}-2 \quad(40-2=38)$ diperoleh $\mathrm{t}_{\text {tabel }}$ 2.024. Berdasarkan hasil analisis data nilai yaitu $t_{\text {hitung }}>\mathrm{t}_{\text {tabel }}(13.220>2.024)$ maka hipotesis diterima.

Uji Paered samples test dimana data yang diuji yaitu hasil data hunbungan literasi dalam pembelajaran bahasa Indonesia pada kelas eksperimen pre test dan post test diperoleh sebesar niali sg (2-tailed) sebesar $0.000<0.05$, maka kita dapat disimpulkan bahwa terdapat perbedaan yang nyata antara hasil pengaruh literasi dalam pembelajaran bahasa Indonesia pada data pre test dan post test bahasa Indonesia dari kelas eksperimen dan kelas kontrol di peroleh $t_{\text {hitung }}$ sebesar 13.220 dengan $\mathrm{dk}=\mathrm{n}-2 \quad(40-2=38)$ diperoleh $\mathrm{t}_{\text {tabel }}$ 2.024. Berdasarkan hasil analisis data nilai yaitu $t_{\text {hitung }}>t_{\text {tabel }}(13.220>2.024)$ maka hipotesis diterima.

\section{KESIMPULAN}

Berdasarkan rumusan masalah dari hipotesis yang diajukan, serta hasil penelitian yang didasarkan pada analisis data dan pengujian hipotesis, maka kesimpulan yang dapat dikemukakan dalam penelitian ini yaitu terdapat pengaruh literasi dalam pembelajaran bahasa Indonesia pada siswa kelas IV SD Inpres 12 Kabupaten sorong pada tahun ajaran 2018/2019. berdasarkan hasil analisis data nilai yaitu $\mathrm{t}_{\text {hitung }}>\mathrm{t}_{\text {tabel }}$ $(13.220>2.024)$, ini berarti bahwa $t_{\text {hitung }}$ lebih besar dari pada $t_{\text {tabel }}$ pada taraf 5\% sehingga hipotesis dalam penelitian ini diterima.

\section{DAFTAR RUJUKAN}

Ariani, E. E. (2018). Pemanfaatan Literasi Dalam Pembelajaran Sejarah Indonesia Di SMA Negeri 1 Kasihan. Skripsi.

Dhea Anatasya, D. (2019). Pembelajaran bahasa indonesia di sekolah dasar. Jurnal Pembelajaran Bahasa Indonesia Di Sekolah Dasar, (pembelajaran bahasa indonesia di sekolah dasar), 1-9.

Kharizmi, M., \& Almuslim, U. (2015). Kesulitan siswa sekolah dasar dalam 
meningkatkan kemampuan literasi. Kesulitan Siswa Sekolah Dalam Meningkatkan Kemampuan Literasi, 2(2), 11-21.

Matondang, Z., \& Pendahuluan, A. (2009). Validitas dan reliabilitas suatu instrumen penelitian, 6(1), 87-97.

Rumaf, N., \& Wahyuningsih, A. (2020). PENERAPAN GAYA LITERASI READ AND WRITING BAGI SISWA DI SD LABSCHOOL STKIP MUHAMMADIYAH SORONG WARMON KOKODA KABUPATEN SORONG. Jurnal Abdimasa, 3(1), 21-27.

Santoso, H. (2016). Jurnal Pendidikan Bahasa dan Sastra Indonesia. Jurnal Pendidikan Bahasa Dan Sastra
Indonesia, 1(budaya literasi dalam pembelajaran bahasa), 12-16.

Sugiyono. (2017). Penelitian Kuantitatif. Pemaparan Metode penelitian Kuantitatif, 2, 16. Retrieved http://repository.uinmalang.ac.id/1985/2/1985.pdf

Triyono, T., \& Dharma, U. W. (2018). Teknik sampling dalam penelitian, (March). ttps://doi.org/10.13140/RG.2.2.1967 4.24003

Ummul Khair. (2018). Pembelajaran Bahasa Indonesia dan Sastra (BASASTRA) di SD dan MI. Jurnal Pendidikan Dasar, 2(1), 81-99 